\title{
No Measure for Culture? Value in the New Economy
}

\author{
Steffen Böhm and Chris Land
}

School of Accounting, Finance and Management

University of Essex,

Wivenhoe Park

Colchester, CO4 3SQ

Tel. 01206873843

cland@essex.ac.uk; steffen@essex.ac.uk

Submitted to Capital \& Class as 'main article', April 2008

Word Count:

\begin{abstract}
About the authors
Steffen Böhm is Lecturer in Management at the University of Essex. He holds a PhD from the University of Warwick. His research focuses on the politics of organising. He is co-founder and member of the editorial collective of the open-access journal ephemera: theory \& politics in organization (www.ephemeraweb.org), and co-founder and co-editor of the new open publishing press mayflybooks (www.mayflybooks.org). He has authored Repositioning Organization Theory (Palgrave) and co-edited Against Automobility (Blackwell). He has been involved in a range of political movements. Between 2003 and 2005 he co-organised a series of three Radical Theory Forums, whose aim was to discuss the possibilities of anti-capitalist organising today.
\end{abstract}

Chris Land teaches Management at the University of Essex. Both his teaching and research are concerned with the possibility of a critical approach to the study of management and organization, informed by a broadly Marxist analysis of capitalism combined with post-structural understandings of the relationship between power, knowledge and subjectivity, and an anarchist valorization of resistance and autonomy. He has written on a range of topics including the shifting constellation of subjectivity, language and technology, the social organization of piracy, and the labour process of management consultancy.

An early version of this paper was presented at the Work, Employment \& Society (WES) Conference, held at the University of Aberdeen, Scotland, 12-14 September 2007. We would like to thank the participants of our conference workshop for their valuable comments. 


\title{
No Measure for Culture? Value in the New Economy
}

\begin{abstract}
This paper explores the articulation of the value of investment in culture and the arts through a critical discourse analysis of policy documents, reports and commentary since 1997. It argues that in this period discourses around the value of culture have moved from the direct economic contributions of the culture industries to indirect economic benefits. These indirect benefits are discussed under three main headings: creativity and innovation, employability and social inclusion. These in turn are analysed in terms of three forms of capital: human, social and cultural. The paper concludes with an analysis of this discursive shift through the lens of autonomist Marxist concerns with the labour of social reproduction. It is our argument that, in contemporary policy discourses on culture and the arts, that government in the UK is increasingly concerned with the use of culture to form the social in the image of capital. As such we have to turn our attention beyond the walls of the factory in order to understand the contemporary capitalist production of value.
\end{abstract}

\section{Introduction}

Due to their use of semi- or non-industrial modes of symbol production, the visual arts have a formally marginal or 'peripheral' position within the creative, or cultural, industries (Hesmondalgh, 2006: 13). Nevertheless, when it comes to autonomy, the arts, and artists, are often granted a privileged position within those industries as an exemplar of unalienated work (Shorthose and Strange, 2004; Wittel, 2004). In part this exemplarity is doubtless due to the apparent irreconcilability of high-culture and the economy. As Bourdieu (1993) characterised it, the field of cultural production is 'the economic world reversed' in that economic success is often a sign of artistic failure for artists and writers. If an artist reaches a mass audience, or enters into standardised, industrialised production, then their status as 'artist' becomes questionable. Rather, artists offer an example of apparently 'unalienated' work by seemingly remaining autonomous and free from both the pressures of the market and from the hierarchical industrialization of their labour process (Wittel, 2004). In idealised artistic production, product and process, form and content, are independently determined within autonomous 'communities' of cultural production (Shorthose and Strange, 2004). The artistic community determines what counts as 'good' art and the individual artist determines both the aesthetic projects they undertake and the conduct of their own labour process.

This apparent autonomy means that the visual artist has become something like a litmus test for autonomy within the creative industries and can be held up as a measure for other creative processes seeking to escape the logics of industrial-capitalist organization. In commentary on peer-to-peer and open-source software production, for example, there is an emphasis on the way in which those involved in coding are recognised by their virtuosity and skill in crafting 'good' code (Raymond, 2001; Sennett, 2008). The standard for what is 'good' code is not determined by an external market or line-manager, as would be the case in a commercial software company, but rather by peer evaluation that can reflect factors and judgements quite specific to the actors involved in production, for example, the ingenuity or quality of 'the hack' (Jordan and Taylor, 2004). As with artists, the value of such work is autonomously determined by informal peer evaluation and pays off in terms of an economy of cultural prestige rather than conventional, monetary economic terms (Rehn, ****). Whether this form of production is compared to a pre-industrial economy of guild-based craftsmanship (Sennett, 2008) or a post-modern, 
community-based digital gift economy (Rehn, ****; cf Teranova, 2004) the focus on autonomy and independence from industrial capitalist systems of organization and evaluation are central to such analyses and reflect assumptions about cultural production that are deeply ingrained in suppositions about artistic production and creativity. As Shorthose and Strange (2004: 47) put it, "Artistic labour is inherently linked to autonomy and self-determination, if it is to be a real and genuine expression of creative labour power."

Within these 'creative communities', or 'creative ecologies' (Shorthose and Strange, 2004) productive activity is conducted according to autonomously determined social values, decided through the on-going and repeated, social interactions of the community members. This renders such relations distinct from both the formal, hierarchical relationships of the employment relationship, and the impersonal, fetishism of the market. Removed from both of capitalism's main structures for evaluating and controlling labour, the work of the artist lies 'beyond value', as Hardt and Negri (2000; Negri, 1999) would put it.

... the value of artistic labour is difficult to quantify or measure because of its collective, intangible nature and its independence from formal market exchange, where prices provide an index (however misleading and distorted) of social value. However, clearly the artistic and cultural labour of the creative ecology makes a substantial contribution to the general welfare of society and its communities. (Shorthose and Strange, 2004: 49)

It is this apparent autonomy and immeasurability of artistic production that we take issue with in this paper. Rather than rehearsing the various conceptual debates there have been over immeasurability and affective, or immaterial, labour (see Harvie, 2006 for a recent summary of, and contribution to, this debate) we examine some of the discursive strategies that arts organizations and the government have developed in addressing the difficulty of measuring the value of the arts. Working with the results of a critical discourse analysis of governmental policy documents, academic and think-tank publications, consultancy reports and industry analyses, we suggest that, far from supporting a strategy of autonomous production, the state, in the UK at least, has been active in seeking to overcome the difficulty of measuring artistic labour by developing new metrics and understandings of cultural and artistic value. The study focuses primarily upon the second of these, examining how 'cultural' and 'artistic' value has been articulated in these documents rather than looking in detail at how these conceptions of cultural value have been operationalised in particular technologies of evaluation. Our findings suggest that, since 1997 at least, there has been a clear tendency, in line with the 'new public management' (ref. ****) to move away from the more marketised systems of control and evaluation followed by the Conservative government in the 1980 and early 1990s, toward more bureaucratic forms of management and evaluation in the arts. This rearticulation has shifted the 'value' of the arts away from directly economic factors, such as profitability or even less direct economic benefits like tourism and job creation in supportive service industries, toward more issues such as education and training, social inclusion, and community cohesion. As we suggest, rather than considering these as resulting from confusion over the boundaries between the social and the economic, the fact that government increasingly articulates the 'return on investement' in the arts in such social terms suggests a deepening of, and enrolment of the arts in, what Negri refers to as the 'real subsumption' of the social under capital. Often this is such a direct attempt at subsumption that these benefits are referred to in terms of 'human capital' and 'social' or 'cultural' capital. The first of these comprises both formal and informal education and training that result in the generation of transferable skills like creativity and enterprise. The latter concepts are mobilised in often quite imprecise ways but we use them here to refer to the ways in which the documents examined suggest that the arts can increase social 
engagement by both facilitating the generation of productive networks and encouraging a culture of 'aspiration' that, through an engagement with the arts, will raise individuals abilities to engage productively with capitalist society.

\section{Evolving Discourses of Evaluation and Measurement in the Arts}

A broad picture has been painted in the policy studies literature (e.g. Matarasso, 1997; Mizra, 2006) in which, during the 1980s under a Conservative government, the arts in the UK were seen as a business like any other, and subject to the rule of the market and supply/demand economics. In this period many galleries and museums had to fight hard for a share of the limited subsidies available. Within the Thatcher government's neo-liberal emphasis on efficiency through markets, where organisations competed for limited resources in a Darwinian fight for survival, the idea of 'subsidy', like 'unemployment benefits' and other forms of social welfare, were seen as both an unnecessary tax burden hampering the growth of the national economy, and an unjustified intervention in the market that would support parasitic and weak organisations. Through the 1980s and early 1990s subsidies to the arts were cut and theatres, galleries and museums were supposed to compete alongside other forms of entertainment for customers' attention and money. In such a climate, subsidised culture had to justify itself on relatively narrow economics grounds, for example: increased tourism, urban regeneration and benefit to local business (Holden, 2004: 15). Where subsidies were not available, organisations were forced to compete for the public's money with more popular cultural and entertainment activities, pushing admissions costs up and reinforcing the notion that the arts were only for a small elite. Nevertheless, within the constraints of reduced funding and the imperatives of the market, the management of the arts was pretty much left alone. The principle of self-determination, and the ability of those in the arts to decide what to spend their resources on, and how to account for this expenditure, was similar to the freedom that any other manager or entrepreneur might expect in this time of hands-off government.

With the change of government to New Labour in 1997, this discourse also changed. Culture was a centrepiece of Blair's vision for Britain, captured in the media friendly idea of a 'Cool Britannia'. Whilst much of this discourse focussed on the music industry and popular culture, there was also a place in this policy orientation for the arts and what had traditionally been seen as 'high-culture'. Galleries and museums were to have their admissions costs removed to democratise access and the total spend on culture increased by $73 \%$ in real terms over the next 10 years (DCMS, 2007: 5). This was not, however, framed as an increase in 'subsidy', but as an increase in 'investment' (Gray, 2002: 84). Of course, as with any investment, there has to be a pay-back. This was not, however, necessarily supposed to be in the form of direct financial returns. Metrics were devised, and promises made, that investment in the arts would pay off in other ways, for example through indirect economic benefits and by delivering on other areas of policy concern, such as social inclusion, crime and health. The kind of indirect economic benefits promised, and sometimes reported, included increased tourism, local regeneration and the development of cultural quarters to attract the 'creative class' that have been constructed as the key value producer in the new economy (Matarasso, 1997; Florida, 2002).

As well as direct and indirect economic impacts of investment in culture and the arts, the last ten years have seen a range of other social and policy relevant benefits being promised. Participation in the arts has been claimed to benefit individuals and communities by improving health, reducing crime, increasing social inclusion and community cohesion, and generally contributing to a sense of 
'well-being'. Although not strictly financial benefits, these social benefits are economic in the broader sense of contributing to the economic health of the region and nation (Matarasso, 1997). It is to a discussion of these that the next section turns, as we present a discourse analysis of government policy documents and publications by funding bodies, think-tanks, consultants and academics.

\section{The Social Impacts of Culture and the Arts: A Critical Discourse Analysis}

\section{Creativity and Innovation}

Much of the discourse on the 'social impacts' or 'value' of the arts is suffused with the ideas that, in the UK at least, we are living in a knowledge economy, or a creative economy. This framework is often so implicit in policy, think-tank and consultancy writings on investment in culture and the arts that it is not even articulated explicitly. Rather, words like 'creativity' and 'innovation' are scattered throughout the documents without necessarily pointing to any specific economic benefits. The assumption seems to be that 'creativity' is a good thing in itself and is a transferable skill with the implication that developing the population's artistic creativity will deliver creativity and innovation in other sectors. In some documents, however, the link is explicit. On the first page of 'Values and Visions: The Contribution of Culture', a document jointly produced by a consortium of organisations involved in funding and administering culture, the bold claim is made that:

In the future, Britain's economic prosperity and well-being will not depend on industrial prowess, natural resources or cheap labour but on developing, attracting, retaining and mobilising creativity. In this 21 st century, goods, services and industries driven by knowledge and creativity will define Britain's competitive edge. This can only happen if its economic strategy is fed by social changes that make culture and creativity part of everyone's life. (ACE et al, 2006: 1)

In the same document, the organisations signing up to it advocate 'promoting a society that values knowledge' and 'encouraging creativity and innovation' (ACE et al, 2006: 3).

For the organisations involved in producing 'Values and Vision', this focus on innovation and creativity cuts two ways. On the one hand, culture and the arts can deliver value by contributing to the creativity of Britain's workforce. On the other hand, they themselves need to innovate if they are to effectively deliver on this promise. The final page of the document gently reminds any politicians of the importance for increased funding of culture and the arts, by proclaiming the need to

invest in the future by encouraging innovation and experiment, by using new technologies to devise new ways of presenting and enjoying culture, and by ensuring that every member of society has equal access to all that we have to offer, and actively takes part in everything we do. (ACE et al, 2006: 12)

These two quotes, from the beginning and end of this document, demonstrate well the current situation of the arts. Despite increased funding under New Labour, culture still has to demonstrate its significance to wider policy concerns, in this instance through the economic-value producing functions of creativity and innovation. Also, although funding has increased, it has not always kept up with increasing demands placed upon museums and galleries. In a House of Commons Report from 2002, for example, it was noted that 'There has been a long term decline in the value of public funding' (HoC, 2002: 15) that had actually been exacerbated by the introduction of free admissions. Since the removal of admissions fees, more people were visiting museums and galleries, extending the social benefits attributed to cultural engagement, but only at the cost of a 'concomitant increase 
in wear and tear on the fabric of the institutions and increased demands on staff for front-of-house services and security' that was not being recognised by compensatory funding increases (HoC, 2002: 15).

As well as a plea for additional funding, this discourse introduces an additional layer of meaning to innovation and creativity in the arts. To deliver on policy promises and have social impacts beyond the small elite traditionally associated with high-culture, the arts must reach a wider population. It will only be able to do this if it is able, as a sector, to innovate its organisational structures and methods of cultural delivery (cf. Harris, 2006).

These twin concerns coalesce in some of the reports we studied around the idea of new media and information and communication technologies (ICT). For example, in a newsletter from firstsite:newsite, a visual arts gallery that is still under construction in Essex, it was reported that 'advances in technology and new media tools provide opportunities to expand way of engaging with art both in and out of the building' (firstsite, 2007: 5). In a similar vein, though playing more heavily on the economic benefits of organisational and technical innovation in the arts, Matarasso notes that many of the projects his report reviewed

used non-hierarchical and co-operative structures to promote a creative work environment. This was especially evident among the digital technology projects where, although there was often a central figure, there was also a high level of delegation and autonomy, with minimal reporting required... Structures were fluid, with people taking on roles according to need, and moving easily between employment, contract work and volunteering. As a result, the projects were adaptable, and willing to give people their head, allowing them to follow and idea in the knowledge that it might fail. The results are not only a series of innovative projects like person-centred profiling, or Internet radio, but new organisational models which allow creativity to thrive. (Matarasso, 1997: 59)

In combination with his other reports on how innovative, ICT-based arts projects helped disengaged young people into work, for example in Harlem and London (1997: 21) as well as in Helsinki (1997: 23; Kelly et al, 1997), Matarasso links together creativity, socio-technical innovation and risk-taking with learning new, highly marketable, technology-based skills.

Although the education and training aspects of these last examples spills over into our second category (below), it is worth noting here the links between organisational form and innovation. For Matarasso, one of the sources of innovation in the arts is that participation is often not heavily formalised, but takes places within a shifting and flexible, constellation of participants, volunteers, contractors and employees. In this he (e.g., 1997: 59-62) reflects post-Fordist discourses of flexibility and entrepreneurial risk-taking with their emphasis on empowerment, critiques of hierarchy and bureaucracy, and use of the network metaphor, ideas that are also commonplace in writings on knowledge work (e.g., Newell et al, 2002). In so doing, his study of the social impact of the arts contains a series of normative assumptions that dominated the popular managerial, as well as economic, discourses of the 1990s, most notably the idea of precarious and insecure employment situations being empowering and liberating workers from stifling bureaucracy that killed creativity (cf. Boltanski and Chiapello, 2005).

\section{Education, Training, Skills and Employability}

As already mentioned in relation to innovation and creativity, several of the documents we studied make links between participation in the arts, the development of transferable skills, and employability. This is particularly prominent in relation to projects using new media. For example, 
Matarasso reports on the success of Finnish projects working with young people using digital technologies where the skills learned on the projects could be directly utilised in employment:

The digital technology projects were often important routes to employment, enabling and encouraging the acquisition of high level and relatively rare skills. As a result, many of those involved - who also tended to be young, and not to have previous success in education or employment - found themselves in possession of highly marketable skills... trainees had found employment in areas ranging from word processing to graphic design and desktop publishing; in the last year, five teenagers had left the project to take up programming. (Matarasso, 1997: 23)

Matarasso also points to the use of participative arts projects in schools, noting that their value goes beyond that of the arts as a subject area: 'Whatever value the arts have in their own right in the curriculum (and they have much), their potential for supporting broad educational goals should be recognised' (Matarasso, 1997: 19). For example, he found that participation in the arts could have a positive impact on the development of language skills, physical coordination, observation skills, social skills and, most notably, creativity and imagination, linking back to the previous category.

Although there is much reference to broad, life-long learning and skills development in the documents, there is also a strong focus on the importance of art galleries and museums for formal education. The House of Commons report on free admissions from 2002 even goes so far as to suggest that the arts should be cross-subsidised from education budgets (HoC, 2002: 7). In their newsletter, firstsite, the Essex-based arts organisation, suggest that 'One in 10 children from the north Essex area has taken part in our educational activities' (firstsite, 2007: 5) and include a number of pictures of children engaged in art projects in their schools and at the 'newsite' site (2007: 5; 2). In 'Values and Vision' the Arts Council of England and its collaborators make much of the use of museums by school children and make explicit the contribution to knowledge and learning that arts and cultural institutions make:

$83 \%$ of visitors say that the museum or gallery visited was an exciting place to visit, with $80 \%$ also saying that they had gained new knowledge and understanding as a result of their visit. (ACE et al, 2006: 11)

This conjunction of education and fun was not unusual. The House of Commons report in particular was at great pains to point out that, although museums in particular were of great scientific and educational importance, 'Perhaps most importantly these institutions are also fun and fascinating places to visit' (HoC, 2002: 9). By combining fun and learning, these reports fit well with contemporary discourses on the value of life-long learning and the need for education, like work, to be both enjoyable and to extend beyond the classroom or workplace (Edwards, 1997). Of central importance here seems to be engaging students who may otherwise be failed in the classroom. As Matarasso notes:

Teachers were often surprised at the level of concentration and effort their pupils were prepared to give to art activities and at the engagement of unexpected children. They spoke at length about the new self-confidence which some of the quieter members of the class had acquired as a result of shining in the art sessions. (1997: 20)

Matarasso continues to suggest that the arts can be a way of engaging children in education outside the classroom, catering for otherwise neglected groups with specific educational needs, such as disabled children (1997: 20) and adults, for whom participation in the arts could provide a route into more formalised learning, for example through full-time further education or and open-university degree (1997: 21).

A local government association (LGA) report into value in the arts in Essex referred to education and training in terms of 'human capital': 'skills and experiences gained by the individual but sustained beyond the life of the arts experience' (LGA, 2003: 39). The survey suggested that 
participants 'reported a positive contribution to their confidence, modes of thinking and personal well-being' (2003: 40) following the activities. Often this increased confidence led to a more conventional development of individual human capital, as $75 \%$ of participants reported that they had 'decided to start some further training or a college course' (2003: 41). Thus, human capital focuses on issues of employability, learning, transferable skills and training. Often this is formalised through education, though not necessarily so. Whilst some reports focus on the educational resources provided by arts programmes and cultural activities for schools, particularly when housed in dedicated venues, other discussions of human capital are more diffuse and suggest that any exposure to the arts can increase human capital.

In combination, these first two categories suggest that the arts generate positive social impacts by indirectly contributing to the economy. Through training, education, developing creativity and creating a space for experimentation and risk-taking, the arts contribute to the development of forms of human capital that can subsequently be deployed in the workplace, or through less formalised economic activities as part of a shifting, post-Fordist, flexible, networked form of organisation that includes volunteers and unpaid labour (Terranova, 2000; Ross, 2000; Arvidsson, 2007). The emphasis on otherwise marginalised groups, however, brings us on to our third category of analysis.

\section{Social Inclusion and Community Cohesion}

Social inclusion is a significant theme in the literature on the social impacts of the arts and is often approached through the concept of community cohesion. The main argument is that the arts can facilitate social inclusion by bringing in the disengaged, socially excluded, or marginalised: those who, for whatever reason, find themselves outside of mainstream society.

In our analysis this is developed in two directions. On the one hand, there is an, often implicit, critique of multi-culturalism, and, on the other, there is a more class-based critique. In the first strand the ideas of national culture and national heritage are invoked and the arts are seen as a way of ensuring a coherent national identity. In more extreme cases this draws a comparison with totalitarianism. As Eleonora Belfiore has commented:

The idea that the arts can help shape people's beliefs and sense of identity - which is central to contemporary debates about the impacts of the arts - has had a central place throughout history in developing the arts and culture for propaganda and indoctrination purposes in non-democratic and totalitarian political systems. (2007: 8)

Belfiore is, of course, quite intentionally drawing parallels to extreme political situations to show that the social impacts of the arts are not always positive. Nevertheless, her point is valid and it has long been recognised in cultural studies that culture plays a central role in the production and regulation of collective identities such as nationality (Anderson, 1991; Eagleton, 2000) and in legitimating colonial rule (Said, 1993).

In the current discourses there is a strong undercurrent that feeds upon similar sentiments, celebrating the superiority of British culture and assuming the need for a strong, national culture to create social cohesion. On the first page of 'Values and vision', British culture is unequivocally celebrated as a national asset:

Our mission is to ensure that Britain's culture, already internationally celebrated for its creativity and style, remains a world leader. (ACE et al, 2006: 1) 
In the next paragraph, the document implicitly calls for a unified culture, albeit dressed in the language of liberal humanist, democratic participation:

\begin{abstract}
We have made great strides toward ensuring that no one is excluded from the benefits of the public investment we represent, but this is only the beginning. By engaging with communities on their own terms, we are now moving from a world where we try to guarantee access to cultural events, places and services to one where participation by the whole community is the norm. Cultural institutions provide the glue that binds communities together... Arts, drama and music help us to explore our emotions and to understand what makes us human. Communities cannot thrive without these cultural experiences that help us to gain a deeper sense of our selves and our shared heritage. Society cannot restore respect or a sense of worth to communities with police and anti-social behaviour orders alone. Without cultural services and cultural experiences communities die. (ACE et al, 2006: 1-2)
\end{abstract}

There are strong tensions at play in this extract. The suggestion that communities must be engaged on their 'own terms' acknowledges difference, but only within limits laid down by a universal humanism where everyone is presumed to share the fundamental identity of 'human', to which a universal 'culture' presumably speaks. Cultural development, this discourse suggests, must be managed within an overarching framework of social integration and regulation. To be excluded is to be failed by society, but also to need saving and bringing back into the fold. Clearly the terms for what the dominant culture is are determined by the cultural institutions that set themselves up as the custodians of 'our' collective memory and imagination. In the 'values and vision' document, this tension appears particularly starkly as the language moves between 'nation' and 'national' - for example when discussing the role of the arts in celebrating national identity in the run up to the London Olympics - and 'community', suggesting a more localised, and perhaps subaltern, identity.

This implicit critique of multi-culturalism sits alongside a second sense of 'social exclusion' that refers more to matters of poverty, class and youth. In this strand the discourses find the causes of poverty, deviance and crime in social, or rather cultural, marginalisation. Matarasso, focussing on youth crimes like vandalism, suggests that crime, and the fear of crime, can be reduced by participative arts projects that bring together the generations and strengthen community ties (1997: 34). Perhaps the starkest example of this version of the social inclusion argument is presented by Jowell (2004: 3), however, who claims that Beveridge's goal of ending 'physical poverty' has been thwarted because it failed to address 'the poverty of aspiration which compromises all our attempts to lift people out of physical poverty'. For Jowell, the social function of culture is precisely to 'alleviate this poverty of aspiration' (2004: 3).

Jowell's essay is a complicated and contradictory document. In places she appears to be arguing against the instrumentalisation of the arts and advocating more of an 'arts-for-art's sake' argument (Jowell, 2004: 8; cf. Belfiore, 2006: 34). This argument for an autonomous, 'bottom-up' (Jowell, 2004: 9) development of culture is, however, consistently undercut by her concerns with alleviating the 'poverty of aspiration' she has identified at the heart of physical poverty and social exclusion. Thus, in places she discusses the need to offer 'improved access to culture for what it does in itself... to understand it and speak up for it on its own terms' (2004: 8), her conception of what culture 'does in itself' is subsumed under a more general idea of personal development and self-actualization, where the consumption of culture enables everyone to realise their potential and engage more fully with society:

Culture alone can give people the means better to understand and engage with life, and as such is a key part in reducing the inequality of opportunity and which can help us slay the... poverty of aspiration. This must be the next priority in the mission at the core of this Government: to transform our society into a place of justice, talent and ambition where individuals can fulfil their true potential. (Jowell, 2004: 17-18)

Of course, all of this assumes two things. First, that everyone's ambition will, once realised through 
cultural engagement, be identical and can be fulfilled within the confines of contemporary society. Without this assumption, social exclusion cannot be remedied by culture. Indeed, if engagement with political art might lead people to reject parliamentary democracy and capitalism tout-court, then social disengagement could potentially increase as a result of cultural participation. Rather, for Jowell, culture fulfils an inherently conservative and socially-integrating function, socialising deviant individuals back into mainstream (or at least government sanctioned) society and aligning their individual aspirations and desires with that of 'the nation' as a whole, or at least its self-proclaimed spokespeople. In this model, culture appears as a tool of government for controlling the population and ensuring that their interests are allied with the dominant socio-economic formation. Of course, such a strategy is unlikely to work and in practice the field of cultural production is striated with lines of antagonism and can be highly political in both its form and content (Bourdieu, 1993; Benjamin, 2002). For the purposes of further exploring the relations between culture and the economy, however, it is worth noting how issues such as 'personal development' and 'aspiration' are coded in relation to capital within these discourses on investment in the arts.

The second assumption made by the argument that culture can reduce social exclusion is that the problem is, at root, a question of individual attitude, perception and 'aspiration', rather than more systemic or structural factors. From a policy perspective this leads to politicians abrogating responsibility for addressing social justice directly. Indeed, it would seem that New Labour has taken on board the Thatcherite idea that there is 'no such thing as society' and opted instead to focus on the community as the most appropriate level for governmental intervention (cf. Rose, 1996). This neglect of 'society' figures prominently in the literature on the social impact of the arts. As Paolo Merli puts it, referring to Matarasso's suggestions that the arts can resolve social exclusion:

\begin{abstract}
Many intellectuals have started looking at society as a mere fact: they do not venture questions, hard criticism and struggle any more; they increasingly behave like "new missionaries", who play guitar with marginalised youth, the disabled and the unemployed, aiming at mitigating the perception which they have of their own exclusion. Indeed, it does not seem that "feeling differently" (Matarasso, 1997, p.101) about the place where one lives will transform slums into wonderful places, nor that... having "a positive impact on how people feel" (Matarasso, 1997, p.x) will change people's daily conditions of existence - it will only "help" people to accept them. However, making deprivation more acceptable is a tool to endlessly reproduce it. (Merli, 2002: 112-113)
\end{abstract}

As Merli notes here, these models of remedying social exclusion without changing the material conditions of exclusion are profoundly conservative. With very few exceptions, and then in academic publications, such issues of profound social change are completely ignored within the discourses on the social impacts of the arts. Instead, the combination of 'social exclusion' and 'community' pushes the responsibility for marginalisation back onto the marginalised, assuming that they simply need their attitude, rather than their material conditions, readjusting - perhaps through the judicious consumption of 'culture' - simultaneously concealing and maintaining the wider social power relations that produce and reproduce inequality and exclusion in the first place.

\title{
Human, Social and Cultural Capital
}

All three of these categories mobilised in discourses concerned with the evaluation of culture and the arts - creativity, employability, and social inclusion - relate to, and are discussed in terms of three aspects of capital. The relationship is not one of a clear mapping of one aspect of capital onto each category, but there is a general tendency to relate employability with an individualised human capital and community cohesion and social integration with social capital. Cultural capital is less often used, perhaps because of its association with the more critical writings of Bourdieu and the 
analysis of class? Even the distinction between human and social capital is not entirely clear, with both often referring to skills and employability. As an LGA report defines it, social capital is: 'The application of skills and experiences by the individual that facilitate co-ordination for mutual benefit' (2003: 39). Here the big promise is to address social exclusion and create 'social capital' as strong bonds of collective identity, mutual support and networks of cooperation at the local level. For example, the LGA report claimed that ' 81 per cent of participants reported that they have become involved in other community projects' (2003: 41), referring to this as 'active citizenship'. Here, then, the arts are seen as central to the development of social entrepreneurs whose creative energies will revitalise both the local culture and economy.

In Jowell's (2004: 16) essay, already discussed, she is quite explicit that 'culture is an important investment in personal social capital'. Although it is unclear exactly how this 'justifies that investment on culture's own terms' (2004: 16) it is fairly clear, in the context of her wider concerns with social exclusion and the poverty of aspiration, that her idea of 'social capital' is predominantly concerned with skills and employability. Indeed, these quotes are taken from a paragraph of the essay dealing with education. In Jowell's framework, then, 'investment' in culture, both governmental and personal (for example, through time spent consuming arts activities), has a pay off in terms of 'social capital'. In Jowell's sense of the term, perhaps 'cultural capital' would be a more appropriate term, although the heritage that this term carries from Bourdieu's (1984) work sits ill at ease with Jowell's assertions that culture is inherently open and inclusive, taking the form of a public good, rather than a commodity (e.g., Jowell, 2004: 5), whose 'excellence' can be brought to the masses without detriment to its inherent value (2004: 10). The concept of 'social capital', on the other hand, particularly in the light of the popularity of the term since Putnam's (2000) Bowling Alone, chimes well with the focus in these documents on 'community'. As several commentators have noted in recent years, the rise of the discourse of 'community' has served to marginalise discussions of 'society' and actively conceal social-structural inequalities and factors in favour of community and individual empowerment (Merli, 2002; Rose, 1996). In such a framework of understanding, social inequality is the result of inadequate assimilation into the 'community'. By strengthening the collective identity of the community, investing in 'culture' can strengthen 'social capital', which people can then leverage for further acts of social entrepreneurship.

These policy documents seem to assume that the community is the appropriate level of social cohesion and is the social space within which the arts and culture can have the biggest impact. Community has, within these discourses, become a calculable 'capacity' that can be maximised:

They are indicators of the cultural resource base, the community capacity, and the cultural capital which exist at local level and which are not well represented in higher level data and indicators produced by national and regional agencies. But this form of capital - cultural, social and human - is the fundamental resource base for any sustainable cultural economy and the crucial link between cultural capacity, social cohesion and economic development. (LGA, 2003: 11)

The key point raised in this quote is that, within these discourses, culture enables a form of sustainable community which will maximise 'cultural capital', enabling a local community with strong social cohesion (measured by social capital) and augment individual human capital (by enhancing creative capabilities, 'well-being', 'confidence', reconnecting people to formal training and educational opportunities (as part of the government's project of 'life-long learning'), as well as through the social networks they are able to leverage) and thereby deliver economic value and development. In short, human development and community development is here subordinated, though the mechanism of culture, to the interests of economic development and capital. 


\section{Capitalising on Culture: Social Reproduction as Measured Labour?}

Our analysis has shown how policy documents and commentary consistently relate the social impacts of culture and the arts to forms of indirect economic benefit. In general these benefits take the shape of three specific forms of capital: cultural, human and social. These terms are not, by any means, clear cut and often overlap, are used interchangeably, or are left ill-defined and vague. Nevertheless, there is a degree of consistency in the articulation of 'social impacts' as 'capital'. Like discourses of social capital more generally, they occlude wider social divisions and structural inequalities, seeking to intervene at the individual, community and social level, by building social capital through integration and conformity with national culture and political-economic status quo (Das, 2006; Merli, 2002; cf. Rose, 1996). On the other hand, there is a consistent emphasis on the value of culture and the arts in terms of the benefits to the economy. In this respect we see both a denial of wider power relations and, at the same time, an effective subordination of culture, and cultural work, to the social reproduction of capitalism, which, in our view, has important implications for the conceptualisation of cultural and artistic work as productive labour.

\section{Cultural and Artistic Work: Unproductive or Productive Labour?}

There is a long standing debate in Marxist political economy over the significance of the distinction between productive and unproductive labour (Harvie, 2006; Cámara Izquierdo, 2006; Mohun, 1996) the details of which are beyond the scope of this paper. However, drawing upon recent theory influenced by autonomist Marxism, we would like to suggest that this dichotomy is increasingly untenable in part, at least, because of changes in the production and circulation of contemporary value (Dyer-Witheford, 1999; Harvie, 2006; Arvidsson, 2007; De Angelis, 2007). The basic contours of this argument suggest that classical Marxist theory draws a clear line between productive and unproductive labour, with the former focussing specifically upon waged labour that directly produces commodities and the latter encompassing everything from the labour of superintendence and circulation, which do not produce value in themselves, but only secure or realise surplus value for the capitalist, to 'reproductive labour' (Harvie, 2006). Reproductive labour is a crucial category in these debates as, in Marx's original formulation, the labour involved in reproducing the commodity labour-power was not deemed to be productive labour (Harvie, 2006: 135), an assertion that has been contested by the autonomists (Dyer-Witheford, 1999; Dalla-Costa and James, 1973) as well as those concerned with the wider economic relations between work in the home and in formal employment (e.g., Oakley, 1974; Glucksmann, 1995; 2005).

With the shift of attention in business in western economies away from the production of material commodities and on to the production of consumption and branding, this distinction becomes even harder to maintain. When organisations are increasingly capitalising directly on culture, the boundaries between productive and unproductive labour, in the classical Marxist sense, dissolve. As Arvidsson (2007) has noted in his study of advertising and event management in Denmark, the employees of advertising agencies are increasingly cast in the role of events coordinator or administrator, whilst the content of their advertising campaigns is produced by the unpaid work of those active in the countercultural underground. In his study of the launch of a new VW car, the launch event consisted of a series of 'underground', countercultural parties and artistic productions, the content of which had been autonomously determined by those recruited to produce them. As these producers were not concerned with economic reward, other than insofar as it enabled them to throw a great party, but with prestige within their own scene, these events were not produced for a 
wage in any conventional sense, and were not oriented toward the production of a simply alienable commodity. By retaining control over the form and content of the event, other than the presence of VW executives and motoring press reporters, these unpaid producers were doubly 'free' in the sense that Terranova (2004) uses when she refers to 'free labour': 'free' to work as they chose on an autonomous project, and 'free' in the sense of being unpaid. Of course, for both of these reasons they would count as unproductive labourers under a narrow interpretations of the term 'productive'. They neither receive a wage nor produce commodities. Despite this, one can readily argue that they produced much of the value of the commodity they were publicising, whether they were remunerated for this or not.

The key here is that the 'value' of most, if not all, commodities today is constituted to a large extent by their symbolic value (cf. Baudrillard, 1993; Arvidsson, 2006). Branding has assumed the position of the dominant locus of 'value added' and a key determinant of the value of a specific commodity is the logo it bears rather than the cost of materials or labour gone into producing it. As Klein's (2000) study of sweatshop labour and apparel production found, Nike trainers retailing at the top end of the fashion sneaker market are produced in the same factories, by the same workers, as no-label, low end trainers. The difference was the symbolic significance of the brand.

What these examples demonstrate is the current significance of 'cultural work'. In each case culture is being produced by the work of participants, but not for a wage and not as a simple commodity, as would be the case in the traditional models of the cultural industries. This idea of culture as work resonates with the autonomist concept of immaterial labour articulated by Lazzarato (1996), who splits immaterial labour into two aspects, the informational and the cultural. The informational aspect refers to 'changes taking place in workers' labor processes... where the skills involved in direct labor are increasingly skills involving cybernetics and computer control' (Lazzarato, 1996: 133). The second aspect "regards the activity that produces the "cultural content" of the commodity... a series of activities that are not normally recognised as "work"... the kinds of activities involved in defining and fixing cultural and artistic standards, fashions, tastes, consumer norms and, more strategically, public opinion' (Lazzarato, 1996: 133). Traditional definitions of 'work', and their restriction to the production of commodities, are further problematised by Lazzarato's (1996: 142) recognition that this kind of immaterial labour involves both 'producers' and 'consumers'. The contemporary production of content for websites like YouTube, MySpace and Facebook would be a good example of this blurring distinction. Whilst most of these sites are owned by for-profit companies, whose business model is based on selling advertising space on their pages, the actual content is produced by users for no direct financial remuneration. In most cases, the reward for participation is the participation itself. As in Arvidsson's (2007) study, prestige within the networks is the pay off. In other cases, such as the web-board moderators discussed by Terranova $(2000 ; 2004)$, the work of providing a product for AOL was similarly unpaid and performed either for status or for the cost of the internet access required to perform the moderation (see also Harvie, 2006: 154).

Seen as a form of immaterial labour, participation in culture and the arts blurs boundaries. The 'productivity' of this labour is unclear, as there is no simple commodity being produced, and it is not remunerated by a wage. Despite this, we would argue, it is productive. This point partly explains the focus on participation in the arts found in many of the studies cited as evidence for the beneficial social impacts of the arts. Matarasso (1997: iv) suggests that he focuses on 'participation because it is to this area of the arts that social benefits are most commonly attributed in policy discussion', and yet, in reality direct participation accounts for only a small amount of cultural 
engagement (Merli, 2002; Belfiore, 2006). What participation does highlight is the activity, or labour, that goes into cultural engagement. But what is produced by this work? The products of such labour can, of course, be commodified. Community arts projects can produce revenues, for example through amateur theatrical productions, but this is not usually the case and when these projects are calling for public funding, such a narrow economic rationale will not stand up. As we have argued above, the pay off for investment in the arts is not in the form of financial capital, but rather through a series of indirect economic payoffs in the areas of human, social and cultural capital.

\section{The Reproduction of the Social as the Value of Culture}

So, what exactly are these forms of 'capital' and how are they capitalised? What is the value produced by cultural work? Our argument is that the product of cultural work is the reproduction of the social itself. Participants, in the roles cast for them by policy documents and impact analyses, are exhorted to work upon their selves and invest in their 'human capital'. As the focus on training, transferable skills, creativity, innovation and learning all suggest, participants are being encouraged do develop the productivity of their labour power, in accordance with hegemonic discourses around the knowledge or creative economy, so as to command a higher price for it in the labour market. But they are also being encouraged to think of themselves as 'human capital', not as labour. To see themselves reflected in the mirror of capitalism as a production function that needs investment and work (through participation in the arts) to realise a surplus value for the owner (the subject him or herself, though the real beneficiary is capital itself, as no 'benefit' can be realised until the labour power thereby produced is subsequently deployed).

A similar argument can be made concerning the concept of social capital mobilised in these discourses. It has been argued that production is increasingly dependent upon networks of social cooperation as evinced by the popularity, across the sectors, of discourses on teamwork, corporate culture management and communities of practice (Brown, 1998; Wenger et al., 2003). Of course, from the outset, capitalism was dependent upon the collectivisation of labour to increase productivity simply through the efficiency gains of natural cooperation (Marx, 1976; Negri, 1989). With the division of labour, productivity increases even further, but does so at the cost of natural cooperation. The Fordist model of organisation takes this perhaps the furthest, by insisting upon the complete subordination of the individual worker to the socio-technical system of the factory but, as Dyer-Witheford (1999) notes, this system also created problems by making the bifurcation between capital and labour all too obvious. The age of mass-production was also the age of the mass-worker, a recalcitrant workforce all too aware of its common fate at the hands of industrial capital.

The balance of power was shifting in the 1960s and 1970s with strong unions, hostile labour relations and increasing industrial unrest in many Western countries. In response to this, autonomists have argued, capital disaggregated, breaking up the vertically integrated factories of the early 20th century in favour of more distributed networks of production with workers reorganised in these networks as customers and suppliers, team-workers or subcontractors. This also shifted the focus on communication. Under the era of the mass-worker communication was prohibited. On Ford's production line workers could not talk to one another. With the new systems, as Lazzarato (1996) recognises in his first aspect of immaterial labour, communication is essential to both organisation and production. Through actively working to produce, reproduce, and innovate within these networks of social cooperation, labour itself takes on the principle function of the 
reproduction of these cooperative networks (Negri, 1989: 51). From this perspective, the age of the mass worker has passed over into the age of the social worker, whose main function is the reproduction of the social itself, but who is also increasingly subject to control through socialisation (Dyer-Witheford, 1999).

Whether this line of argument is empirically accurate, or speaks to the workplace realities of the majority of the population even in 'advanced' western economies is a moot point (cf. Thompson, 2005). Nevertheless, it seems to us that the argument does point toward a historical tendency. Changes in the organisation of the capitalist enterprise have taken place and, at least for certain segments of the labour forces, collaboration, communities and teams are increasingly the norm. Even if there is a gap between the rhetoric and the reality, managerial discourses on the importance of cooperation, eliciting full participation through teamworking or leveraging collective knowledge and creativity through communities of practice abound (Newell et al, 2002; Wenger et al, 2003).

At the very least, these ideas have had an impact on the kinds of policy documents on the arts and culture that we have been concerned with in this paper. Read from this perspective, the invocation of 'social capital' and community building in policy documents relates both to a new mode of government for such populations, one that had moved decisively from mass-society and the Fordist compromise of Keynesian economics and a welfare state to ameliorate the working class, to one where the class has itself been fragmented and recomposed at the level of the community (Hardt and Negri, 1994; Rose, 1996). Within this new framework, however, communities are being encouraged to self-govern, in similar ways to workplace teams self-organising. The imperative is clear that such communities must contribute to the functioning of the overall whole, so that the nation does not disappear, but becomes the focal point of integration for individuals and communities (Hyland, 2006). And this contribution has, of course, to be measured and evaluated in order to become controllable, manageable and malleable.

\section{Beyond Measure? The Value of Cultural Work Today}

The question of measure has become a hotly debated topic amongst autonomist Marxists in recent years (see, for example, Hardt and Negri, 2000, 2004; Caffentzis, 2005; De Angelis, 2005, 2006; Harvie, 2006; Dowling, 2007). The source of the controversy is the claim by certain autonomist Marxists that today's labour is 'beyond measure' or 'immeasurable' (Hardt and Negri, 2000: 294; 2004: 145), which is based on the 'real subsumption' thesis discussed earlier. Hardt and Negri's argument is that today it is increasingly difficult to distinguish between labour and capital, as capital has subsumed labour completely: 'capital is the totality of labor and life' (Negri, 1991: 122). Based on a reading of Marx's Grundrisse and the second volume of Capital (Marx, 1973, 1992), Hardt and Negri argue that today capital should be seen as 'total social capital', meaning that the social itself has become capital, and capital has become life itself. In other words, work is not only that which produces value in the limited realms of the labour process. Instead, work is limitless today as it involves a whole range of communicative, immaterial and affective aspects that produce the social and life directly (Lazzarato, 1996). It is for this reason that Hardt and Negri $(2000,2004)$ argue that labour has become 'immeasurable'.

Following this logic, artistic and cultural work can be seen as the labour that reproduces 'total social capital' in two senses: First, capital is inserted into the interstices of the reproduction of 'culture' itself and culture becomes a commodity. This is the traditional 'culture industry' thesis, which 
suggests a continuous commodification and 'sell out' of culture to capital (Adorno and Horkheimer, 1979). While this process of commodification is, no doubt, ongoing, the second sense of the 'total social capital' thesis points to the role culture plays in the reproduction of the social and life as such. While we agree with the basic contours of this argumentation by autonomist Marxists, we share the views of commentators, such as Wittel (2004), Dowling (2007) and De Angelis (2006), who doubt the claim that this totality of social capital is automatically 'beyond measure'.

Wittel (2004), for example, states that the post-Fordist economies, however unstable and contingent, still work functionally and effectively, for which measure is needed: 'So, de facto, the affective dimensions of labour are constantly measured. Although this measuring is difficult, it is also imperative' (2004: 26). This constant need to measure immaterial and affective work, which is supposedly 'beyond measure', is empirically shown by Dowling (2007) in her critical, auto-biographical assessment of work in a restaurant. In quite some detail she discusses the mechanisms through which she was subjected to forms of control, showing how her work was intensely measured and hence its nature altered.

This need for measuring labour and life in the post-Fordist society is also explained by De Angelis, for whom 'measure' is a necessary part of any social body: 'A measure is always a discursive device that acts as a point of reference, a benchmark, a typical norm, a standard. It is thus a relational reference point that guides action of a singular body subject, yet it carries the weight of the habits, traditions and cultures of the social body.' (De Angelis, 2006: 176, emphasis in original). Based on Marx's work, De Angelis distinguishes between external and immanent measures of value. The external measure is the normal price tag that capital puts onto commodities, such as labour. For example, the city worker earns ten times as much as the nurse, which is a way of saying that we, as society, value stockbrokers much more than nurses caring for the sick and elderly (f. Elson, 1979). De Angelis agrees with Hardt and Negri that we cannot stop there; that is, this external measure does not tell us the whole story about how value is produced today. In addition, we need to recognise the immanent forms of work today, which reproduce the social and life as such. In contrast to Hardt and Negri, however, De Angelis argues that this immanence is very much part of a measurement regime as well. For him, the immanent measure of value

\begin{abstract}
corresponds to that labour which is socially necessary for the production of a commodity. As its corresponding external measure, this immanent measure of value is also constituted by the ongoing working of capitalist disciplinary processes (and therefore value struggles) passing through markets, as well as their state-implanted simulations. ... And when we bring this reflection to the foreground, we realize that the disciplinary mechanism that creates commodity values is at the same time the disciplinary mechanism that attributes value to the social actions that produce those commodities, that creates patterns of how we produce them, what we produce, how much of them we produce, how we relate to each other in producing them, what system of needs we create, and how we distribute our social doing, our social labour across the social body. (De Angelis, 2006: 180, emphasis in original)
\end{abstract}

In other words, it is not only the external measure of commodity value that disciplines the worker, but also the immanent measures of value, which aim at disciplining all aspects of life of the social body. Culture and the arts are subjected to both external and immanent measures of value. Externally, it is part of a general commodification process that turns cultural and artistic materials into commodities. However, in addition, the immanent role of culture and the arts is to govern and discipline the social body in order to guarantee a continuous reproduction of capital. It is this important immanent role that makes it necessary for the state to measure and govern the social impacts of culture and the arts.

We have argued in this paper that, while the Thatcher regime was mainly concerned with ensuring 
that culture and the arts are increasingly subjected to the general commodification process of capital, New Labour has extended this logic by concentrating its governing efforts on 'improving' the immanent measure of the value of culture and the arts. It is for this discursive shift from Conservative to New Labour cultural policies that we think Shorthose and Strange's (2004) valorisation of the autonomy of cultural and artistic work misses the point. While we clearly see the possibility of such autonomy - which correspondents to the second face of Dyer-Witheford's (2002) 'value subjects', namely the autonomous subjectivity that is capable of resisting hegemonic regimes of value and actively forging new values - Shorthose and Strange (2004) do not take sufficient account of those powerful discourses of governance that already point beyond narrow economist evaluations of culture and the arts. So, when they claim that "artistic and cultural labour ... makes a substantial contribution to the general welfare of society and its communities", and when they see "such artistic labour, social reciprocity and trust-based exchange contribute substantially to the quality of life of its producers and consumers" (Shorthose and Strange, 2004: 49), then New Labour is on their side. That is, New Labour would not necessarily disagree with Shorthose and Strange's autonomist, 'art for art's sake' argument, as our above discussion of Jowell (2004) has shown. However, it is precisely because of culture's importance for the 'general welfare of society and its communities' that the government sees an increasing need to control and measure cultural and artistic work, as our analysis of policy documents has shown.

\section{Conclusions}

The aim of this paper has been to explore the ways in which culture and the arts have been articulated in relation to wider society and the economy in recent years. Our analysis of policy documents has shown that there has been a discursive shift from the Thatcherite regime of governance, which mainly emphasised the need for culture and the arts to become part of the commodity market, toward a New Labour discourse that highlights the important role of culture and the arts for the general welfare of society. Our analysis has shown that this discursive shift has led to a general tendency toward evaluating and measuring culture and the arts in relation to policy interests that are external to the immediate concerns of the field of cultural production. While today policies that seek to make culture and the arts directly economically productive have not disappeared, the discourse represented by New Labour involves more complex articulations of the value of culture and the arts for wider social measures such as 'well-being', 'health', 'education', 'creativity', 'innovation', 'social inclusion', 'human capital' and 'social capital'. Our aim was to discuss this discursive shift in relation to contemporary conceptions of capitalism.

Our argument has been mainly inspired by autonomist Marxist authors who have argued that today capital should be understood as 'total social capital', i.e. capital that has completely subsumed the social. While writers such as Hardt and Negri $(2000,2004)$ argue that this totality implies that contemporary work and labour are 'beyond measure', our analysis of cultural policy discourse has shown that measurement and evaluation is still very much part of the way the capital-state regime reproduces itself. Following De Angelis (2006), we have argued that capital as well as the state have an instrumental interest in applying both 'external' and 'immanent' measures of value to culture and the arts in order to, first, capitalise on the cultural industries for continuous economic growth, and, second, use culture and the arts as instruments for the social reproduction of labour. We have argued that in both of these ways cultural and artistic labour needs to be understood as productive labour. 
incorporate following into the conclusions and directions for further research? Idea would be to suggest that focusing on producers, rather than the full circuit of production, valorises a specific conception of creativity that will tend to recapture it as 'skillful' or 'knowledgeable' or even 'creative' labour...

An interesting, and slightly confusing, argument is presented on p.145 where Hesmondalgh notes the widening remit of the 'creative industries', which include areas like software development (and much more when we come to Florida and Howkins a page later). This conjunction enables the 'moral prestige' of the creative artist to be mobilised in defence of IPR for industry. More importantly, I think, is the notion that this also pushed a model of transferable skills whereby creativity could move between the arts, culture and ICT. This in turn directly influenced education policy toward a more 'skills' oriented approach and, according to Hesmondalgh, pushed the focus onto the artist rather than the audience and infrastructure. This is probably so, except that where the audience is discussed, through participation in cultural events etc, they are themselves seen as enhancing their creativity and skills. Consumption can no longer be passive, but must be active: it must become work that will increase the value of the participant's labour power (through skills development or just by enhancing their ambition, 'aspiration' and motivation. After all, as David Harvie (2006) has noted directly, and Boltanski and Chiapello (2005) imply with their analysis of the crisis of capitalist social reproduction in the 1960s, labour power needs both practical skills and motivation to effectively valorise capital.

\section{References}

Adorno, T.W. and Horkheimer, M. (1979) Dialectic of Enlightenment, trans. J. Cumming. London: Verso.

Anderson, B. (1991) Imagined Communities: Reflections on the Spread of Nationalism. London: Verso.

Arthur, C.J. (2004) 'Value and negativity: a reply to Carchedi', Capital \& Class, 82: 17-22.

Arts Council of England, The National Museum Directors' Conference, The Museums, Libraries and Archives Council, The Association of INdependent Museums, The Group for Large Local Authority Museums, The Museums Association, The University Museums Group (2006) Values and Vision: The Contribution of Culture. Available on-line at: http://www.nationalmuseums.org.uk/images/publications/values_and_vision_no_pics.pdf

Arvidsson, A. (2006) Brands: Meaning and Value in Media Culture. London: Routledge.

Arvidsson, A. (2007) 'Creative Class or Administrative Class? On Advertising and the 'Underground', ephemera: theory \& politics in organization, 7(1): 8-23, http://www.ephemeraweb.org/journal/7-1/7-1 arvidsson.pdf

Baudrillard, J. (1993) Symbolic Exchange and Death. London: Sage.

Belfiore, E. (2004) 'Auditing culture', International Journal of Cultural Policy, 10(2): 183-202.

Belfiore, E. (2006) 'The social impacts of the arts - myth or reality?', in Mizra, M. (ed.) Culture Vultures: Is UK Arts Policy Damaging the Arts? London: Policy Exchange.

Belfiore, E. (2007) 'A Matter of Values', Arts Professional, 140 (26 February): 8-9.

Belfiore, E. and Bennett, O. (2007) 'Rethinking the Social Impact of the Arts', International Journal 
of Cultural Policy, 13(2): 135-151.

Benjamin, W. (2002) 'The Author as Producer', in S. Dunscombe (ed.) Cultural Resistance Reader. London: Verso.

Blair, T. (2007) 'Cultural speech at Tate Modern', 6 March 2007, http://www.number-10.gov.uk/output/Page11166.asp

Boltanski, L. and Chiapello, E. (2005) The New Spirit of Capitalism. London: Verso.

Bourdieu, P. (1984) Distinction: A Social Critique of the Judgement of Taste. London: Routledge.

Bourdieu, P. (1993) The Field of Cultural Production: Essays on Art and Literature. Cambridge: Polity.

Bowring, F. (2004) 'From the mass worker to the multitude: A theoretical contextualisation of Hardt and Negri's Empire', Capital \& Class, 83: 101-132.

Brown, A. (1998) Organizational Culture. London: Financial Times Pitman Publishing.

Caffentzis, G. (2005) 'Immeasurable Value? An Essay on Marx's Legacy', The Commoner, 10: $87-114$

Cámara Izquierdo, S. (2006) 'A value-oriented distinction between productive and unproductive labour', Capital \& Class, 90: 37-63.

Capital \& Class (2004) Special issue on the Creative Industries, 84.

Carchedi, G. (2003) 'A note on Chris Arthur's "dialectics of negativity", Capital \& Class, 81: 25-30.

Dalla Costa, M. and James, S. (1973) The Power of Women and the Subversion of the Community. Berlin: Falling Wall Press.

Das, R.J. (2006) 'Putting social capital in its place', Capital \& Class, 90: 65-92.

Davenport, T. and Prusak, L. () Working Knowledge: How Organizations Manage What they Know. Cambridge, MA: Harvard Business School Press.

Dawson, P. (1994) Organizational Change: A Processual Approach, London: Paul Chapman.

DCMS (2006) 'Creative Industries Economic Estimates Statistical Bulletin', September, http://www.culture.gov.uk/Reference_library/Research/statistics_outputs/creative_industries_ eco_est.htm.

DCMS (2007) Culture and Creativity in 2007. London: DCMS. Available at: http://www.culture.gov.uk/NR/rdonlyres/8B79CCFD-7EF9-4F51-80CC-531134C79575/0/Cu ltureandCreativity2.pdf

De Angelis, M. (2005) 'Value(s), Measure(s) and Disciplinary Markets', The Commoner, 10: 65-86.

De Angelis, M. (2006) The Beginning of History: Value Struggles and Global Capital. London: Pluto.

Dowling, E. (2007) 'Producing the Dining Experience: Measure, Subjectivity and the Affective Worker', ephemera: theory \& politics in organization, 7(1): 117-132.

Drucker, P. (1968) The Age of Discontinuity: Guidelines to our Changing Society. New York: Basic Books.

Dyer-Witheford, N. (1999) Cyber-Marx. Urbana: University of Illinois Press.

Dyer-Witheford, N. (2002) 'Global Body, Global Brain/ Global Factory, Global War: Revolt of the Value-Subjects', The Commoner, January, $\quad$ N.3: http://www.commoner.org.uk/03dyer-witheford.pdf.

Eagleton, T. (2000) The Idea of Culture. Oxford: Blackwell.

Edwards, R. (1997) Changing Places? Flexibility, Lifelong Learning and a Learning Society. London: Routledge.

Fairclough, N. (1995) Critical Discourse Analysis. London: Longman.

firstsite (2007) firstsite:newsite - newsletter 1. Colchester: firstsite. 
Fleming, P. (2005) 'Workers' playtime? Boundaries and cynicism in a "culture of fun" program', The Journal of Applied Behavioral Science, 41(3): 285-303.

Florida, R. (2002) The Rise of the Creative Class. New York: Basic Books.

Florida, R. (2004) Cities and the Creative Class. London: Routledge.

Glucksmann, M. (1995) Why 'Work'? Gender and the 'Total Social Organization of Labour' Gender, Work \& Organization, 2(2): 63-75.

Glucksmann, M. (2005) 'Shifting boundaries and interconnections: Extending the 'total social organisation of labour', The Sociological Review, 53(s2): 19-36.

Grey, C. (2002) 'Local government and the arts', Local Government Studies, 28(1): 77-90.

Grover, C. (2003) "NNew Labour", welfare reform and the reserve army of labour', Capital \& Class, 79: 17-23.

Hardt, M. and Negri, A. (1994) The Labor of Dionysus. Minneapolis: University of Minnesota Press.

Hardt, M. and Negri, A. (2000) Empire. Cambridge, MA: Harvard University Press.

Hardt, M. and Negri, A. (2004) Multitude: War and Democracy in the Age of Empire. London: Penguin.

Harris, M. (2006) 'Technology, innovation and post-bureaucracy': the case of the British Library, Journal of Organisational Change Management, 19(1): 80-93.

Harvie, D. (2006) 'Value production and struggle in the classroom: Teachers within, against and beyond capital', Capital \& Class, 88: 1-32.

Hesmondhalgh, D. The Cultural Industries, 2nd Edition. London: Sage.

Holden, J. (2004) Capturing Cultural Value: How Culture has Become a Tool of Government Policy. London: Demos.

House of Commons (2002) First Report - DCMS - National Museums and Galleries: Funding and Free Admission. London: HMSO.

Hyland, M. (2006) 'Proud Scum: The Spectre of the Ingrate', Mute 2(2): 19-25.

Jacques, R. (2000) 'Theorizing knowledge as work: The need for a 'knowledge theory of value', in C. Pritchard, R. Hull, M. Chumer and H. Willmott (eds.) Managing Knowledge: Critical Investigations of Work and Learning. Basingstoke: Macmillan.

Jowell, T. (2004) Government and the Value of Culture. London: HMSO/DCMS.

Kelly, O., Wojdat, E., and Khan, N.(1997) The Creative Bits, The Social Impacts of the Arts Using Digital Technology. Stroud: Comedia.

Kennedy, P. (2005) 'Social policy, social exclusion and commodity fetishism', Capital \& Class, 85: 91-114.

Kicillof, A. and Starosta, G. (2007) 'Value form and class struggle: A critique of the autonomist theory of value', Capital \& Class, 92: 13-40.

Klein, N. (2000) No Logo: Taking Aim at the Brand Bullies. London: Flamingo.

Lazzarato, M. (1996) 'Immaterial Labour', in P. Virno and M. Hardt (eds.) Radical Thought in Italy: A Potential Politics. Minneapolis: University of Minnesota Press.

Leadbeater, C. (1999) Living on Thin Air: The New Economy. London: Viking.

Local Government Association (LGA) (2003) Creative Consequences: The contribution and impact of the arts in Essex: 2001/02. London: LGA Publications.

Marx, K. (1973) Grundrisse: Foundations of the Critique of Political Economy, trans. M. Nicolaus. Harmondsworth: Penguin.

Marx, K. (1976) Capital: A Critique of Political Economy, Vol. 1, trans. B. Fowkes. London: Penguin.

Marx, K. (1992) Capital: A Critique of Political Economy, Vol. 2, trans. D. Fernbach. London: Penguin. 
Matarasso, F. (1997) Use or Ornament?: The Social Impact of Participation in the Arts. Stroud: Comedia.

Merli, P. (2002) 'Evaluating the social impact of participation in arts activities: A critical review of Francois Matarasso's Use or Ornament', International Journal of Cultural Policy, 8,1: 107-118

Mizra, M. (ed.) (2006) Culture Vultures: Is UK Arts Policy Damaging the Arts? London: Policy Exchange.

Mohun, S. (1996) 'Productive and Unproductive Labor in the Labor Theory of Value', Review of Radical Political Economics, 28(4): 30-54.

Negri, A. (1989) The Politics of Subversion: A Manifesto for the Twenty-First Century. Cambridge: Polity.

Negri, A. (1991) Marx beyond Marx: Lessons on the Grundrisse. New York: Autonomedia.

Negri, A. (1999) 'Value and Affect', Boundary 2, 26(2): 77-88.

Newell, S., Robertson, M., Scarbrough, H. and Swan, J. (2003) Managing Knowledge Work. Basingstoke: Palgrave.

Oakley, A. (1974) The Sociology of Housework. New York: Pantheon.

Paltridge, B. (2006) Discourse Analysis. London: Continuum.

Putnam, R. (2000) Bowling Alone: The Revival and Collapse of American Community. New York: Simon and Schuster.

Rose, N. (1996) 'The death of the social? Re-figuring the territory of government', Economy and Society, 25(3): 327 - 356

Ross, A. (2000) 'The mental labor problem', Social Text, 19(2): 1-31.

Said, E. (1993) Culture and Imperialism. London: Vintage.

Shorthose, J. (2004) 'The engineered and the vernacular in cultural quarter development', Capital \& Class, 84: 159-178.

Shorthose, J. and Strange, G. (2004) 'The new cultural economy, the artist and the social configuration of autonomy', Capital \& Class, 84: 43-59.

Tapscott, D. (1996) The Digital Economy. New York: McGraw Hill.

Terranova, T. (2000) 'Free Labor: Producing Culture for the Digital Economy', Social Text, 18(2): 33-58.

Terranova, T. (2004) Network Culture: Politics for the Information Age. London: Pluto.

Thompson, P. (2005) 'Foundation and Empire: A critique of Hardt and Negri', Capital \& Class, 86: 73-100.

Wenger, E., McDermott, R. and Snyder, W. (2003) Cultivating Communities of Practice. Cambridge MA: Harvard Business School Press.

Wittel, A. (2004) 'Culture, labour and subjectivity: For a political economy from below', Capital \& Class, 84: 11-30.

Work Foundation, The (2007) 'Report hails economic vitality of Britain's creative industries', Press Release, 25 June 2007, http://www.theworkfoundation.com/aboutus/media/pressreleases/ britainscreativeindustries.aspx

Work Foundation, The / DCMS (2007) 'Staying ahead: the economic performance of the UK's creative industries', Report, 25 June 2007, http://www.cep.culture.gov.uk/ index.cfm?fuseaction=main.viewBlogEntry\&intMTEntryID=3095

Wright, S. (2005) 'Reality check: Are we living in an immaterial world?', Mute, 2(1): 34-45. On-line at: http://www.metamute.org/en/node/5594 
